\section{Nickel Effect on Pomegranate Cracking, Nutrient Concentrations, and Biochemical Parameters of Pomegranate Peel}

\author{
Olga Dichala ${ }^{1}$ \\ Laboratory of Biology of Horticulture, School of Agriculture, Aristotle \\ University, Thessaloniki 54124, Greece
}

Ioannis Therios

Laboratory of Pomology, School of Agriculture, Aristotle University, Thessaloniki 54124, Greece

\author{
Magdalene Koukourikou-Petridou \\ Laboratory of Biology of Horticulture, School of Agriculture, Aristotle \\ University, Thessaloniki 54124, Greece
}

Aristotelis Papadopoulos

Institute of Soil and Water Resources, Hellenic Agricultural Organization ELGO-DIMITRA, Thermi, Thessaloniki 57001, Greece

Additional index words. cracking, flavonoids, minerals, nickel, phenolics, pomegranate

\begin{abstract}
A field experiment was conducted in a pomegranate (Punica granatum L.) orchard of the well-known cultivars Wonderful and Acco, located in the farm of Aristotle University. The trees were sprayed, every 15 days from flowering (April) to fruit maturation (September), with solutions containing 0, 25, 50, $100 \mu \mathrm{M} \mathrm{Ni}$, and $100 \mu \mathrm{M} \mathrm{Ni}+$ $100 \mu M B$ prepared with $\mathrm{Ni}\left(\mathrm{NO}_{3}\right)_{2} \cdot 6 \mathrm{H}_{2} \mathrm{O}$ and boric acid. Leaves and fully ripe fruits were initially sorted into cracked and uncracked ones, then further separated into peel and seeds, sampled, and analyzed. Nickel sprays were effective in controlling fruit splitting as well as $\mathrm{Ca}$ and $\mathrm{Mg}$ concentration of fruit peels. The correlation between cracking level and $\mathrm{Ni}$ concentration in solution was linear and negative. Cracking percentage with $50 \mu_{M} \mathrm{Ni}$ was lower in 'Wonderful', whereas no difference was recorded between the cultivars in the remaining treatments. Leaves had the smallest $\mathrm{Ni}$ concentration compared with fruit peel and seeds. Calcium concentration of pomegranate peels was higher than that of control peel at $50 \mu \mathrm{M}$ Ni in 'Wonderful'. Concerning 'Acco', the treatments $25 \mu \mathrm{M}$ Ni, $50 \mu M \mathrm{Ni}$, and $100 \mu \mathrm{M} \mathrm{Ni}+100 \mu \mathrm{B}$ reduced Ca concentration, compared with control. 'Wonderful' fruit peel contained more phenolics than 'Acco'. The treatments 25,50 , and $100 \mu M \mathrm{Ni}$ increased significantly the flavonoid concentration of fruit peels. The antioxidant capacity ferric-reducing antioxidant potential (FRAP) was linearly increased with $\mathrm{Ni}$ concentration in solution in 'Wonderful', whereas in 'Acco' it decreased at 25 and $50 \mu \mathrm{M}$ Ni. Our data indicates that improving Ni nutrition of pomegranate can potentially reduce crop loss due to cracking and modified phenol and flavonoid concentration and FRAP value of fruit peel.
\end{abstract}

Nickel is an essential nutrient element for plants (Epstein and Bloom, 2005) and the last found micronutrient which is required for nitrogen metabolism (Bhalerao et al., 2015),

Received for publication 28 June 2018. Accepted for publication 1 Sept. 2018.

I would like to express my gratitude to Polyxeni Psoma and Areti Bountla for their support and assistance in all of the techniques and methodologies in the laboratory of Soil and Water Resources in the Hellenic Agricultural Institute of ELGO-DIMITRA. This research was partially funded by Aristotle University of Thessaloniki and the Hellenic Agricultural Institute of Soil and Water Resources of ELGO-DIMITRA.

${ }^{1}$ Corresponding author. E-mail: olga.dichala@ gmail.com. affecting the activity of the enzyme urease (Bai et al., 2007). Poor Ni nutrition potentially affects primary metabolism in such a way that endogenous availability of certain aminoacids, organic acids, and acetyl-CoA can potentially limit lignification (Bai et al., 2006).

Cracking or splitting of fruits is a serious physiological disorder of pomegranate which affects yield and quality of fruits (Abd ElRhman, 2010). Fully matured fruits crack because of moisture imbalance because they are sensitive to variation in soil moisture and also to daily and high atmospheric moisture (Ahmed, 2009). Long drought period causes hardening of peel, and if this is followed by rain or heavy irrigation, pomegranate fruit forms cracks (Khalil and Aly, 2013). Crack- ing is controlled by maintaining soil moisture and avoiding its wide variation by application of adequate and regular irrigation (Ahmed, 2009) during fruit growth. Several cultural factors such as rootstock, irrigation, mineral nutrition, pruning, fruit thinning, and spraying with $\mathrm{Ca}, \mathrm{N}, \mathrm{B}$, salicylic acid (Ahmed et al., 2014), and growth regulators such as GAs (Singh et al., 2003) exert much influence on pomegranate cracking control. Furthermore, various minerals affect yield and fruit quality of pomegranate (Kamal et al., 2017). Nickel-repeated foliar sprays reduced waterstage fruit splitting of pecan (Wells and Wood, 2008). The pomegranate peel also is a rich source of tannins, flavonoids, and other phenolic compounds ( $\mathrm{Li}$ et al., 2006). Until now, Ni was not used to reduce fruit cracking of pomegranate or other fruit, except pecan (Wells and Wood, 2008).

The aim of this study is to evaluate the possibility that the pomegranate fruit cracking can be controlled by foliar sprays with nickel (Ni). In addition, this experiment attempts to study Ni effects on total phenolic concentration, total flavonoids, and FRAP value of pomegranate peel and also $\mathrm{Ni}$ accumulation and its effects on $\mathrm{Ca}$ and $\mathrm{Mg}$ in leaves, peel, and pomegranate seeds.

\section{Materials and Methods}

A field experiment was conducted at the farm of Aristotle University of Thessaloniki, Greece, during the period from Apr. to Sept. 2015 (lat. $40^{\circ} 32^{\prime} 04.16^{\prime \prime} \mathrm{N}$ and long. $\left.22^{\circ} 59^{\prime} 41.33^{\prime \prime} \mathrm{E}\right)$. The altitude of the orchard is $\approx 5 \mathrm{~m}$ above the sea level. The monthly mean of minimum temperature during the experiment was $14.9^{\circ} \mathrm{C}$, whereas the maximum was $27.6^{\circ} \mathrm{C}$. The total rainfall during these months was $194.2 \mathrm{~mm}$. Two Punica granatum L. ('Wonderful' and 'Acco') were included in the experiment. Their choice was based on their excellent commercial characteristics. These cultivars are grown extensively in Greece and also in other countries. However, nothing is known about their cracking tolerance of pomegranate fruits, biochemical characteristics, and antioxidant capacity under the influence of $\mathrm{Ni}$ concentration $(0,25,50$, and $100 \mu \mathrm{M} \mathrm{Ni}$ and $100 \mu \mathrm{M}$ $\mathrm{Ni}+100 \mu \mathrm{M}$ B). For convenience, treatments codified as follows: Ni0, Ni25, Ni50, Ni100, and NiB100. Ni was chosen for the cracking experiment instead of $\mathrm{Si}$ because $\mathrm{Ni}$ is the last essential of elements found (Dalton et al., 1988). Ni was applied foliarly and in the soil to avoid its fixation in the negative charges of soil particles. The experiment was conducted using 6-year-old pomegranate plants grown in the experimental orchard. Orchard trees were spaced $5 \times 4 \mathrm{~m}$ and were drip irrigated as needed throughout the growing season. The treated trees did not exhibit any invisible symptoms of $\mathrm{Ni}$ or other nutrient deficiencies and midsummer leaf concentration was within the sufficient range of pomegranate (Kahramanoglu and Usanmaz, 2016). The characteristics of orchard soil in $0-30 \mathrm{~cm}$ depth were as follows: sand (44\%), clay 
(22\%), and silt (34\%); $\mathrm{pH} 7.6$; organic matter $1.77 \% ; \mathrm{CaCO}_{3} 0.80 \%$; and electrical conductivity $0.95 \mathrm{mS} \cdot \mathrm{cm}^{-1}$. Nickel was supplied in the form of $\mathrm{Ni}\left(\mathrm{NO}_{3}\right)_{2} \cdot 6 \mathrm{H}_{2} \mathrm{O}$ sprayed to foliage every $15 \mathrm{~d}$ from April to September. Each treatment included five replications (plants).

The following parameters were measured: 1) percentage of fruit cracking; 2) concentration of $\mathrm{Ni}$ (fruit peel, seeds, and leaves), $\mathrm{Ca}$ (fruit peel and seeds), and $\mathrm{Mg}$ (fruit peel); 3) concentration of total flavonoids and total phenols; and 4) antioxidant capacity of fruit peels. At the termination of the experiment, the pomegranate fruits were harvested and separated in fruits with and without cracking, and the percentage of fruit cracking was determined. Nickel was determined in fruit peel, seeds (after aril removal), and leaves. $\mathrm{Ca}$ was determined in fruit peel and seeds and $\mathrm{Mg}$ in fruit peel. At harvest, the fruits were separated in peel and seeds (aril removal), and also on the same day, a leaf sample was collected (10 leaves from each plant). All samples were washed twice with distilled water, dried at $68{ }^{\circ} \mathrm{C}$ for $48 \mathrm{~h}$, and then grounded to a fine powder to pass through a 30-mesh screen. Dried samples were stored in a cool room $\left(12 \pm 2{ }^{\circ} \mathrm{C}\right)$ until analyzed in one batch, to avoid batch-to-batch variation. Each sample $(1 \mathrm{~g})$ was dry ashed at $520{ }^{\circ} \mathrm{C}$ for $8 \mathrm{~h}$, and in each sample, $5 \mathrm{~mL}$ of $6 \mathrm{~N} \mathrm{HCl}$ was added. Total $\mathrm{Ni}\left(\mathrm{mg} \cdot \mathrm{kg}^{-1}\right), \mathrm{Ca}$, and $\mathrm{Mg}$ were determined (\%) in this extract by using ICP-OES (Perkin-Elmer Optima 2100 DV, Shelton, CT) equipment and a standard solution of $\mathrm{Ni}, \mathrm{Ca}$, and $\mathrm{Mg}$.

Total flavonoids were extracted from $1 \mathrm{~g}$ of fresh tissue in $80 \%$ methanol and determined colorimetrically (Zhishen et al., 1999). Rutin was used as the standard compound for quantification of total flavonoids. All values were expressed in $\mathrm{mg}$ of rutin per gram of fresh weight (FW). The data reported are the means of five replications.

Phenols were extracted from $0.3 \mathrm{~g}$ of fresh tissue in $80 \%$ methanol, assayed using the Folin-Ciocalteu reagent following a standard method (Zhishen et al., 1999) and expressed as mg gallic acid equivalent (GAE per gram FW), which was used for standard curve with a range of 0-125 $\mu \mathrm{M}$ (Scalbert et al., 1989).

To estimate the antioxidant capacity, the FRAP assay was used (Benzie and Strain, 1996). The FRAP assay determines the capacity of antioxidants as reductants in a redoxlinked colorimetric reaction of the reduction of the yellow $\mathrm{Fe}^{3+}$ 2,4,6-tripyridyl-s-triazine to a blue-colored $\mathrm{Fe}^{2+}$ complex at low $\mathrm{pH}$ that is measured spectrophotometrically at $593 \mathrm{~nm}$. The extracts were incubated at room temperature with the FRAP reagent and the absorbance recorded after $1 \mathrm{~h}$. The reducing power is expressed as $\mu \mathrm{mol}$ ferrous sulfate $\left(\mathrm{FeSO}_{4}\right)$ per gram.

The experimental layout included two cultivars, five Ni treatments, and five replications (plants) per treatment. Data were subjected to analysis of variance. For comparison of means, Duncan's multiple range test was used $(P \leq 0.05)$ with the SPSS 24.0 statistical package (SPSS, Inc., Chicago, IL).

\section{Results}

Peel cracking of pomegranate fruits. The percentage of fruit cracking in both the cultivars reached a value of $80 \%$ in the control (Ni0). Spraying of plants from flowering (April) to harvest (September) every $15 \mathrm{~d}$ with solutions containing various concentrations of $\mathrm{Ni}$ resulted in a significant decrease in fruit cracking (Fig. 1). The relationship between \% cracking and $\mathrm{Ni}$ concentration in solution was linear $\left(R^{2}=0.95\right)$ (Table 1) and these parameters were negatively correlated. Fruit cracking with Ni25 was $\approx 70 \%$, with Ni50 was $60 \%$, and with Ni100 was $40 \%$. The treatment of NiB100 did not reduce further the cracking. Cracking $\%$ with Ni50 was less in 'Wonderful', whereas no difference was recorded between the cultivars in the remaining treatments.

Nickel, Calcium, and Magnesium concentrations in leaves, fruit peel, and seeds. Nickel concentration was measured in leaves, fruit peel, and seeds (Fig. 2A-C). Leaves (Fig. 2C) had the smallest Ni concentration compared with fruit peel (Fig. 2A) and seeds (Fig. 2B). Hence, in leaves, Ni concentration ranged from $0.05 \mathrm{mg} \cdot \mathrm{kg}^{-1}$ dry weight (DW) to $0.18 \mathrm{mg} \cdot \mathrm{kg}^{-1} \mathrm{DW}$. In the treatment $\mathrm{NiB} 100$, the maximum $\mathrm{Ni}$ concentration of leaves was $0.05 \mathrm{mg} \cdot \mathrm{kg}^{-1} \mathrm{DW}$ in 'Wonderful'. 'Wonderful' had the greatest leaf Ni concentration of leaves.
In the fruit peel, $\mathrm{Ni}$ concentration ranged from 0.75 to $1.2 \mathrm{mg} \cdot \mathrm{kg}^{-1} \mathrm{DW}$. From the two cultivars at Ni25 and Ni50, 'Wonderful' differed significantly from 'Acco'. However, at Ni100 and NiB100, no difference was recorded between the cultivars. Moreover, $\mathrm{Ni}$ concentration in seeds varied from 0.8 $\mathrm{mg} \cdot \mathrm{kg}^{-1} \mathrm{DW}$ to $1.3 \mathrm{mg} \cdot \mathrm{kg}^{-1} \mathrm{DW}$. Between the cultivars, only at Ni50 a significant difference was recorded. In fact, 'Acco' seeds had twice greater $\mathrm{Ni}$ concentration than 'Wonderful'.

$\mathrm{Ca}$ concentration of pomegranate peel (Fig. 3A) was higher than that of control peel at Ni50 in 'Wonderful'. In the remaining treatments, peel Ni concentration was less in 'Wonderful' compared with that in control. Concerning 'Acco', Ca concentration was lower than control in the treatments $\mathrm{Ni} 25$, $\mathrm{Ni50}$, and NiB100.

In the seeds of 'Wonderful' (Fig. 3B) and up to Ni50, a linear increase in Ca concentration was recorded. Also, with NiB100, calcium concentration was much higher than in control. In conclusion, the treatment Ni50 doubled $\mathrm{Ca}$ concentration of 'Wonderful' seeds. In 'Acco', Ni25, Ni50, and NiB100 reduced $\mathrm{Ca}$ concentration compared with that in the control, whereas at Ni100, it did not differ from control.

The concentration of Ni50 increased two to three times $\mathrm{Mg}$ concentration of peel (Fig. 3C) compared with control, whereas

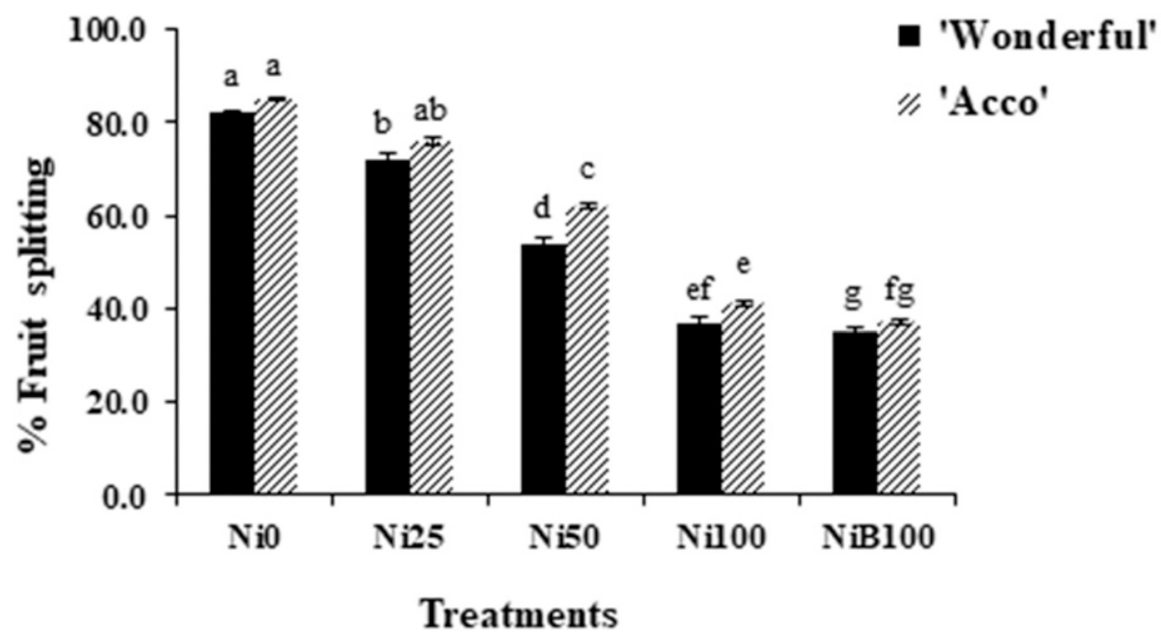

Fig. 1. Effect of five Ni concentrations in spray solution on pomegranate cracking (\%). Averages $( \pm$ SE) followed by the same letter(s) did not significantly differ with each other at $P \leq 0.05(n=5)$.

Table 1. The best linear or quadratic regression model describing the relationship that existed between Ni concentration in solution $(0,25,50$, and $100 \mu \mathrm{M} \mathrm{Ni})$ and $\mathrm{Ni}$ levels in leaves and seeds, fruit cracking, and $\mathrm{Ca}, \mathrm{Mg}$, phenols, and flavonoids concentrations, as well as FRAP values in 'Acco' fruit peel.

\begin{tabular}{lcl}
\hline & $R^{2}$ & \multicolumn{1}{c}{ Equation } \\
\hline Ni (peel) & 0.937 & $y=-0.166 x^{2}+1.0876 x-0.883$ \\
Ni (seeds) & 0.981 & $y=-0.37 x^{2}+2.144 x-1.805$ \\
Ni (leaves) & 0.734 & $y=-0.0075 x^{2}+0.0545 x-0.0525$ \\
Fruit cracking & 0.949 & $y=-15.8 x+104.5$ \\
Ca (peel) & 0.969 & $y=0.025 x^{2}-0.127 x+0.27$ \\
Mg (peel) & 1.000 & $y=0.005 x^{2}-0.025 x+0.03$ \\
Phenols (peel) & 0.918 & $y=-4.21 x^{2}+18.698 x+2.25$ \\
Flavonoids (peel) & 0.981 & $y=5.4725 x^{2}-25.386 x+49.918$ \\
FRAP (peel) & 0.963 & $y=252.55 x^{2}-1120.1 x+2010.2$ \\
\hline
\end{tabular}




\section{Fruit peel (A)}
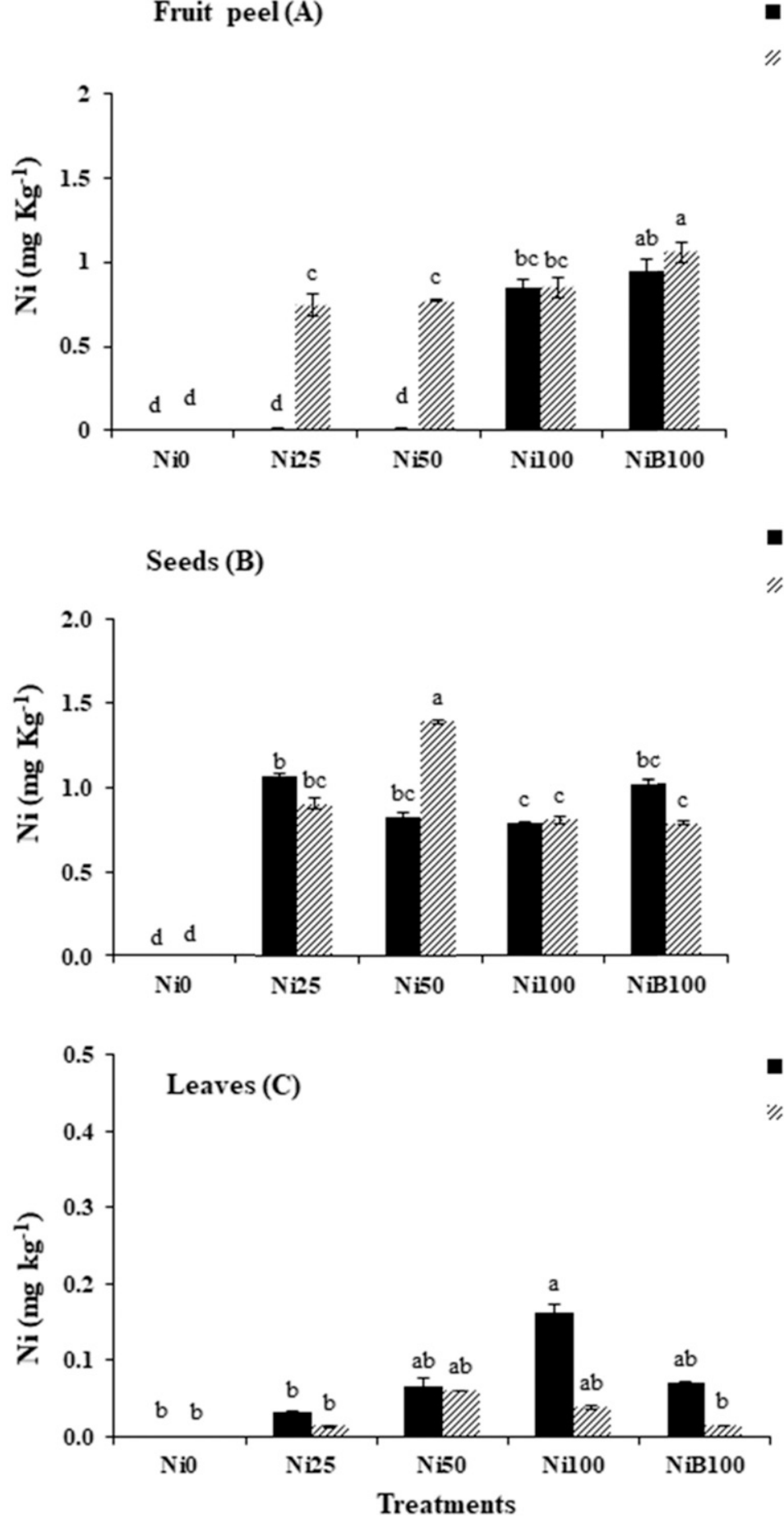

Fig. 2. Effect of five Ni concentrations in spray solution on Ni concentration in fruit peels (A), seeds (B), and leaves $(\mathbf{C})$. Averages $( \pm \mathrm{SE})$ followed by the same letter(s) did not significantly differ from each other at $P \leq 0.05(n=5)$.

the treatment NiB100 did not differ from control.

The relationship between Ni concentration in solution and $\mathrm{Ca}$ and $\mathrm{Mg}$ in pomegranate peel was expressed with a second-degree equation with $R^{2}=0.969$ and $R^{2}=1$, respectively (Table 1).

Total phenols, flavonoids, and FRAP value of pomegranate peel. Total phenols in both cultivars followed a Gaussian pattern (Fig. 4A). 'Wonderful' contained more phe-
- 'Wonderful'

"'Acco'

- 'Wonderful'

"'Acco'

- 'Wonderful'

"'Acco' compared with control. Also, in 'Acco' at Ni100, flavonoid concentrations were as high as in 'Wonderful' at Ni25 and Ni50. At NiB100, 'Wonderful' had the same flavonoid concentration as that in the control, whereas 'Acco' had less concentration than that of control.

The antioxidant capacity (FRAP) (Fig. 4C) was linearly increased with $\mathrm{Ni}$ concentration in spraying solution in 'Wonderful', whereas in 'Acco', it decreased at $\mathrm{Ni} 25$ and Ni50 and increased in both cultivars at Ni100. In the treatment NiB100, the FRAP value of 'Wonderful' was greater than that of control, whereas in 'Acco', the FRAP value decreased. The relationship between Ni concentration in spraying solution and total phenolics, flavonoids, and FRAP value is expressed by a second-degree equation, with $R^{2}$ values $0.968,0.982$, and 0.963 , respectively (Table 1).

\section{Discussion}

Peel cracking in pomegranate causes significant crop loss every year. This occurs after fruit ripening in random shapes from the external to the internal part of fruits. Fruit cracking is not an instant burst, but a gradual process. Nonetheless, in pomegranate, the peel cracking mechanism is still unclear and there is very little data on the morphological properties that influence it (Saei et al., 2014). Studies have shown that weakness of epidermis and formation of sclereid clusters in ground tissue cause cracking in pomegranate (Yazici et al., 2011)

Pomegranate cracking is a physiological disorder which is probably due to moisture imbalance, as this fruit is very sensitive to variation in soil moisture. Prolonged drought causes hardening of peel, and if this is followed by heavy irrigation, the pulp grows and the peel expands in a disanalogous proportion and subsequently cracks (Khalil and Aly, 2013). Pomegranate fruits split when turgor pressure generated within the growing fruit exceeds the capacity of the peel to withstand the pressure without splitting. The capacity of the peel to withstand this pressure is partly regulated by the degree of peel lignification because lignin provides rigidity to peel. The thickness and hardness of fruit peel are directly associated with fruit cracking. Daily variations in sunlight's exposure intensity positively correlate with the daily fruit cracking in Citrus ( $\mathrm{Li}, 2003$ ). Hence, fruits growing on the shaded part of the tree had a significantly greater percentage of fruit cracking (Chen et al., 2005; Li and Chen, 2017). Although many studies have dealt with this complex phenomenon, the basic mechanism involved in pomegranate cracking remained unclear. Therefore, the present study is helpful to examine suitable control measures for pomegranate cracking using Ni sprays. Almost all soils have plenty of Ni (Wood et al., 2006). In addition, the application of $\mathrm{Ni}$ on soils results in strong binding to negative charges of soil particles and poor movement through the soil profile 
Fruit peel (A)

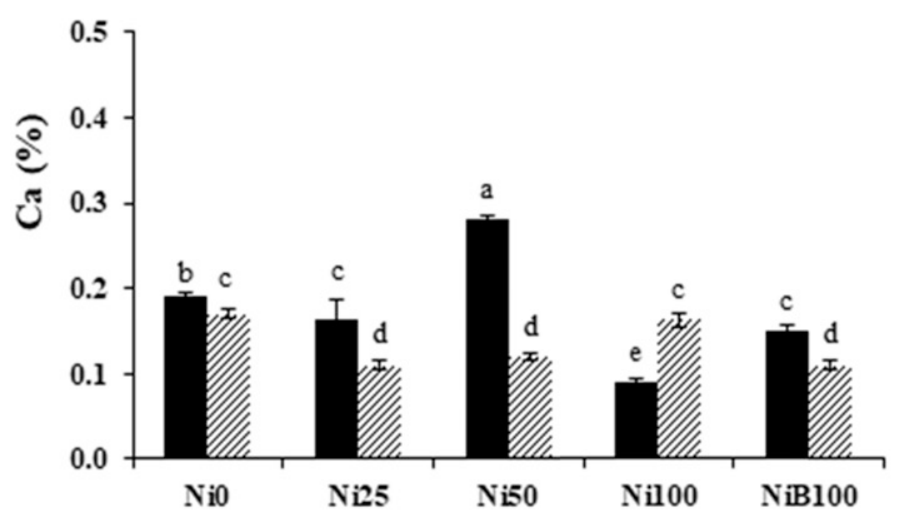

Seeds (B)

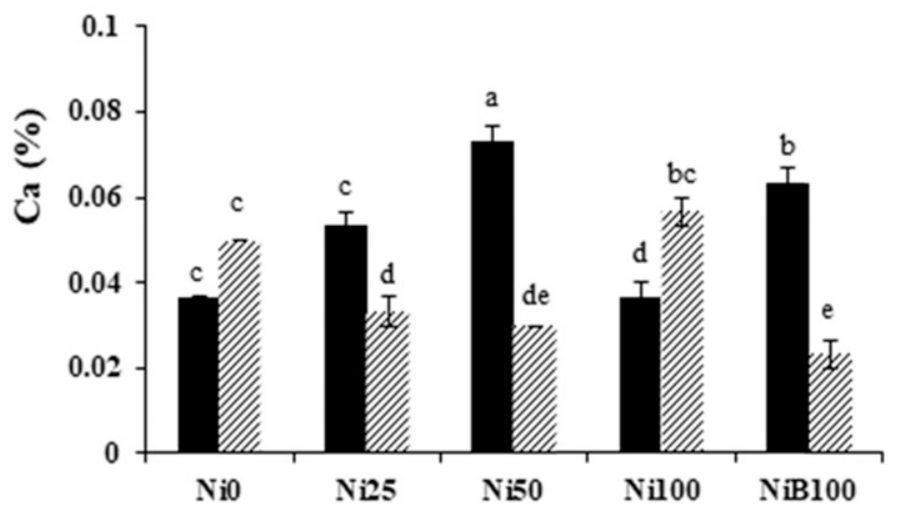

Fruit peel (C)

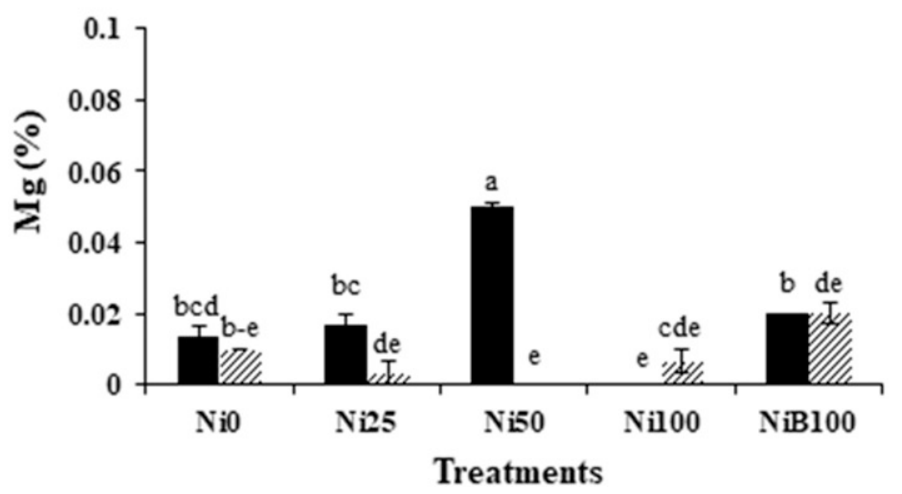

Fig. 3. Effect of five Ni concentrations in spray solution on (\%) Ca concentration in fruit peels (A), seeds $(\mathbf{B})$, and $(\%) \mathrm{Mg}$ concentration in fruit peels $(\mathbf{C})$. Averages $( \pm \mathrm{SE})$ followed by the same letter(s) did not significantly differ from each other at $P \leq 0.05(n=5)$.

because there are soil chemistry issues that limit timely Ni uptake by roots (Wood and Reilly, 2007). It is for this reason that foliar application of $\mathrm{Ni}$ is by far the preferred approach to control pomegranate cracking.

Spraying of $\mathrm{Ni}$ to pomegranate foliage may result in the formation of nanoparticles, which because of their small size possess unique properties. The high surface area to volume ratio of nickel nanocrystals can

- 'Wonderful'

"'Acco'

- 'Wonderful'

"'Acco'

- 'Wonderful'

\%'Acco' sometimes lead to unexpected properti (Angajala and Radhakrishnan, 2014). A particle with high surface area possesses many reaction sites and thus leads to higher chemical reactivities of Ni sprayed on pomegranate. Spraying with Ni reduced significantly pomegranate cracking. The apparent beneficial effect of foliar Ni sprays on reducing cracking losses is consistent with the fact that $\mathrm{Ni}$ nutrition potentially influences lignin metabolism within the immature peel of the developing fruit (Wood and Reilly, 2007). The effect of $\mathrm{Ni}$ on reducing pomegranate cracking could also be possibly ascribed to its effects on the activity of certain enzymes, on shikimic acid pathway (Wood and Reilly, 2007), and on the synthesis of lignin, phenolics, tannin, FRAP value, and level of $\mathrm{Ca}$ and $\mathrm{Mg}$ in the peel.

Skin thickness is an active factor in blocking rain penetration to innermost tissues and reducing the cracking force (Saei et al., 2014). Our data does not allow us to conclude anything regarding the effect of $\mathrm{Ni}$ on skin thickness. Thus, another experiment should be conducted to elucidate this point.

According to Dos Reis et al. (2011), Ni concentration of fruits decreased as Ni rates increased. The cracking rates decreased also with application of salicylic acid, magnesium sulfate, chelated zinc, boric acid, calcium chloride (Ahmed et al., 2014), boron and $\mathrm{GA}_{3}$ (Singh et al., 2003), and paclobutrazol (El-Khawaga, 2007), which can increase cell wall plasticity and promotion of cell extension. The cracking rate could also decrease significantly, by spraying with $\mathrm{K}, \mathrm{Ca}, \mathrm{B}$, and $\mathrm{Zn}$ because $\mathrm{Zn}, \mathrm{B}$, and $\mathrm{K}$ contents of peel increased the thickness of the peel ( $\mathrm{Li}$ and Chen, 2017).

The pomegranate fruit peel contained all minerals (Rowayshed et al., 2013). In the presence of $\mathrm{Ni}$, the concentration of mineral nutrients in plant organs may increase, decrease, or stay constant (Ros et al., 1990). One of the probable mechanisms for decreasing the uptake of macro and micronutrients relies on competition for common binding sites because of the compatible ionic radius of $\mathrm{Ni}$ with other cations.

Foliar application of Ni affected the concentration of $\mathrm{Ca}$ and $\mathrm{Mg}$ in pomegranate peel and seeds, an aspect very important in controlling fruit cracking, because of their role as constituents of cell walls. Ca participates in modifying the metabolism of the cell wall and has interactive effects in cell wall composition and important physiological functions, such as the maintenance of stability of cell wall, and enzyme activity. The formation of tissue cell walls was attributed to the stabilization of membrane systems by the formation of $\mathrm{Ca}-\mathrm{Mg}$ pectates, which increased rigidity of middle lamella and cell wall. Also, $\mathrm{Ca}$ and $\mathrm{Mg}$ are responsible for strengthening the bonds between epidermal and other fruit cells, resulting in greater strength and low cracking of pomegranate fruits. Previous studies (Saei et al., 2014) on biomechanical behavior of plant tissue illustrate that its higher calcium concentration changes plant tissues' biomechanical behavior, making them harder and more brittle and less sensitive to cracking. A relationship exists between the biomechanical behavior of pomegranate fruit skin and its calcium concentration. The calcium effect can be explained by the formation of a calcium bridge between groups of pectin chains. The treatment $\mathrm{NiB} 100$ containing also B reduced significantly cracking. Boron plays an important 

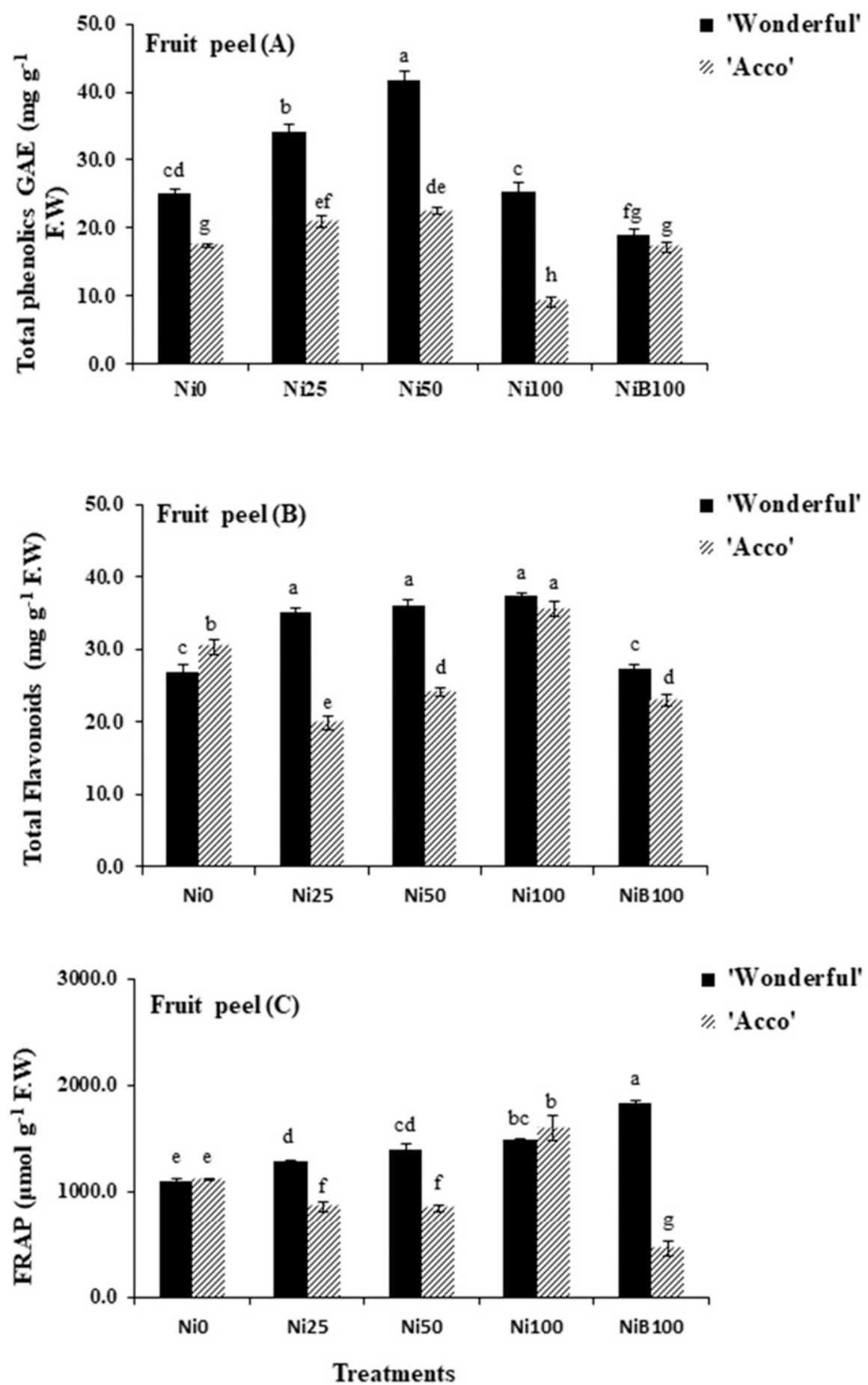

Fig. 4. Effect of five Ni concentrations in spray solution on total phenolics (A), total flavonoids (B), and FRAP $(\mathbf{C})$ in fruit peels. Averages $( \pm \mathrm{SE})$ followed by the same letter(s) did not significantly differ from each other at $P \leq 0.05(n=5)$.

role in the extension of plant cell walls through its association with cell wall pectin (Kaneko et al., 1997). The role of B is also known in plant metabolism including many physiological aspects such as nucleic acid metabolism, building and translocation of carbohydrates, cell wall synthesis, and membrane functions which have an indirect influence on osmotic pressure within plant cells, and decrease of pomegranate cracking (Prativa et al., 2013). Furthermore, B is responsible for increasing the elasticity of cell membranes and prevents the breakdown of vegetative tissues. Thus, the decrease in cracking might be the result of borate bridging with cell wall constituents giving elastic response to it, as advocated by Singh et al. (2002).

The antioxidant capacities of phenolic compounds in pomegranate were studied (ElFalleh et al., 2011). Exposure of plants to Ni sprays has been shown to increase the activities of SOD, POD, GR, and GOPx enzymes to enhance the activation of other antioxidants, and hence leading to scaveng- ing of ROS (Gomes et al., 2006). Nickel's indirect influence on the shikimic acid pathway also was an important implication in that this pathway influences production of certain plant hormones and integrity of structural components such as formation of lignin, phenolics, tannins, and similar compounds that indirectly affect tree performance and orchard productivity (Wood and Reilly, 2007). High Ni concentrations led to a significant increase in electrolytic leakage, reflecting the metal-induced enhancement of membrane permeability (Gajewska et al., 2012). Ni foliar sprays increased in most of the cases the level of phenols, flavonoids, and FRAP value, indicating their possible involvement in reducing cracking percentage. Antioxidant properties of pomegranate peel have been reported (Reddy et al., 2007). The main antioxidant compound in pomegranate juice is hydrolyzable tannins (Gil et al., 2000). The antioxidant activity is higher in commercial juices than in regular ones, which is due to the presence of pomegranate rind tannins. In conclusion, $\mathrm{Ni}$ spray reduced pomegranate peel cracking possibly by increasing the level of phenolics, tannin, FRAP value, and $\mathrm{Ca}$ and $\mathrm{Mg}$ concentration in peels. Our results indicate that foliar application of $\mathrm{Ni}$ can potentially reduce the severity of pomegranate cracking.

\section{Literature Cited}

Abd El-Rhman, I.E. 2010. Physiological studies on cracking phenomena of pomegranates. J. Appl. Sci. Res. 6:696-703.

Ahmed, B. 2009. Fruit cracking and yield of pomegranate as affected by borax with irrigation at different intervals. Ann. Agr. Res. New Ser. 30:148-149.

Ahmed, F.F., M.M. Mohamed, A.M.A. Abou ElKhashab, and S.H.A. Aeed. 2014. Controlling fruit splitting and improving productivity of Manfalouty pomegranate trees by using salicylic acid and some nutrients. World Rural Observations 6:87-93.

Angajala, G. and S. Radhakrishnan. 2014. A review of nickel nanoparticles as effective therapeutic agents for inflammation. Inflamm. Cell Signal. 1:e271.

Bai, C., C.C. Reilly, and B.W. Wood. 2006. Nickel deficiency disrupts metabolism of ureides, aminoacids and organic acids of young pecan foliage. Plant Physiol. 140:433-443.

Bai, C., C.C. Reilly, and B.W. Wood. 2007. Nickel deficiency affects nitrogenous forms and urease activity in spring xylem sap of pecan. J. Amer. Soc. Hort. Sci. 132:302-309.

Benzie, I.F. and J.J. Strain. 1996. The ferric reducing ability of plasma (FRAP) as a measure of "antioxidant power": The FRAP assay. Anal. Biochem. 239:70-76.

Bhalerao, S.A., A.S. Sharma, and A.C. Poojari. 2015. Toxicity of nickel in plants. Intl. J. Pure Appl. Biosci. 3:345-355.

Chen, J.Z., Z.X. Ye, B.Y. Zhou, C.X. Xu, and J. Li. 2005. Effects of pectins and pectinesterase activity on creasing fruit formation in orange (Citrus sinensis Osbeck). Acta Hort. Sinica 32:202-206.

Dalton, A.D., S.A. Russell, and H.J. Evans. 1988. Nickel as a micronutrient element for plants. Biofactors 1:11-16.

Dos Reis, A.R., J.L. Favarin, L.A. Gallo, M.F Moraes, T. Tezzotto, and J. Lavres, Jr. 2011. 
Influence of nitrogen fertilization on nickel accumulation and chemical composition of coffee plants during fruit development. J. Plant Nutr. 34:1853-1866.

ElFalleh, W., N. Tlili, N. Nasri, Y. Yahia, H. Hannachi, N. Chaira, M. Ying, and A. Ferchichi. 2011. Antioxidant capacities of phenolic compounds and tocopherols from Tunisian pomegranate (Punica granatum) fruits. J. Food Sci. 76:C707-C713.

El-Khawaga, A.S. 2007. Reduction in fruit cracking in Manfaluty pomegranate following a foliar application with paclobutrazol and zinc sulphate. J. Appl. Sci. Res. 3:837-840.

Epstein, E. and A.J. Bloom. 2005. Mineral nutrition of plants: Principles and perspectives. 2nd ed. Sinauer, Sunderland, MA.

Gajewska, E., P. Bernat, J. Dlugonski, and M. Sklodowska. 2012. Effect of nickel on membrane integrity, lipid peroxidation and fatty acid composition in wheat seedlings. J. Agron. Crop Sci. 198:286-294.

Gil, M.I., F.A. Tomás-Barberán, B. Hess-Pierce, D.M. Holcroft, and A.A. Kader. 2000. Antioxidant activity of pomegranate juice and its relationship with phenolic composition and processing. J. Agr. Food Chem. 48:4581-4583.

Gomes, R.A., Jr., C.A. Moldes, F.S. Delite, P.L. Gratão, P. Mazzafera, P.J. Lea, and R.A. Azevedo. 2006. Nickel elicits a fast antioxidant response in Coffea arabica cells. Plant Physiol. Biochem. 44:420-429.

Kahramanoglu, I. and S. Usanmaz. 2016. Pomegranate production and marketing. CRC Press, Boca Raton, FL.

Kamal, H.M., M.A. Elisa, and A.A. Mohammed. 2017. Effects of some mineral compounds on yield and fruit quality of pomegranate. Biosci. Res. 14:1197-1203.
Kaneko, S., T. Ishii, and T. Matsunaga. 1997. A boron-rhamnogalacturonan-II complex from bamboo shoot cell walls. Phytochemistry 44:243-248

Khalil, H.A. and H.S.H. Aly. 2013. Cracking and fruit quality of pomegranate (Punica granatum L.) as affected by pre-harvest sprays of some growth regulators and mineral nutrients. J. Hort. Sci. Ornam. Plants 5:71-76.

Li, J. 2003. Cell wall metabolism and related gene isolation of pitting fruit peel in citrus. Guangzhou South China Agr. Univ., PhD Diss. (in Chinese).

Li, J. and J. Chen. 2017. Citrus fruit-cracking: Causes and occurrence. Hort. Plant J. 3:255-260.

Li, Y., C. Guo, J. Yang, J. Wei, J. Xu, and S. Cheng. 2006. Evaluation of antioxidant properties of pomegranate peel extract in comparison with pulp extract. Food Chem. 96:254-260.

Prativa, S., N. Sharma, and D.P. Sharma. 2013 Effect of in-situ moisture conservation, forchlorfenuron and boron on growth, fruit cracking and yield of pomegranate cv. Kandhari under rainfed conditions of Himachal Pradesh Indian J. Hort. 70:501-505.

Reddy, M.K., S.K. Gupta, M.R. Jacob, S.I. Khan, and D. Ferreira. 2007. Antioxidant, antimalarial and antimicrobial activities of tannin-rich fractions, ellagitannins and phenolic acids from Punica granatum L. Planta Med. 73:461-467.

Ros, R., D.T. Cooke, R.S. Burden, and C.S. James. 1990. Effects of the herbicide MCPA and the heavy metals cadmium and nickel on the lipid composition $\mathrm{Mg}^{2+}$-ATPase activity and fluidity of plasma membranes from rice, Oryza sativa (cv. Bahia) shoots. J. Expt. Bot. 41:457-462.

Rowayshed, G., A. Salama, M. Abul-Fadl, S. Akila-Hamza, and E.A. Mohamed. 2013. Nutritional and chemical evaluation of pomegranate (Punica granatum L.) fruit peel and seeds powders byproducts. Middle East J. Appl. Sci. 3:169-179.

Saei, H., M.M. Sharifani, A. Dehghani, E. Seifi, and V. Akbapour. 2014. Description of biomechanical forces and physiological parameters of fruit cracking in pomegranate. Scientia Hort. 178:224-230.

Scalbert, A., B. Monties, and G. Janin. 1989 Tannins in wood: Comparison of different estimation methods. J. Agr. Food Chem. 37:1324-1329.

Singh, R.P., K.N. Chidambara Murthy, and G.K. Jayaprakasha. 2002. Studies on the antioxidant activity of pomegranate (Punica granatum) peel and seed extracts using in vivo models. J. Agr. Food Chem. 50:81-86.

Singh, D.P., B.D. Sharma, and R. Bhargava. 2003. Effect of boron and $\mathrm{GA}_{3}$ to control fruit cracking in pomegranate (Punica granatum). Curr. Agr. 27:125-127.

Wells, M.L. and B.W. Wood. 2008. Foliar boron and nickel application reduce water-stage fruitsplit of pecan. HortScience 43:1437-1440.

Wood, B.W. and C.C. Reilly. 2007. Interaction of nickel and plant disease, p. 217-247. In: L.E. Datnoff, W.H. Elmer, and D.M. Huber (eds.). Mineral nutrition and plant disease. Amer. Phytopathol. Soc. Press, St. Paul, MN.

Wood, B.W., C.C. Reilly, and A.P. Nyczepir. 2006. Field deficiency of nickel in trees: Symptoms and causes. Acta Hort. 721:83-98.

Zhishen, J., T. Mengcheng, and W. Jianming. 1999. The determination of flavonoid contents in mulberry and their scavenging effects on superoxide radicals. Food Chem. 64:555-559.

Yazici, K., L. Kaynak, and M.S. Cevik. 2011. Anatomy of pomegranate (Punica granatum L. 'Hicaznar') fruit exocarp. Acta Hort. 890:215-220. 